\title{
TEMPERATURE AND HUMIDITY FORECASTING IN IRAQ
}

\section{'Zahraa M. Mohammed'}

\section{Seroor A. Khaleefa ${ }^{1}$}

1) Environmental Engineering Department, College of Engineering, Mustansiriyah University, Baghdad, Iraq

\begin{abstract}
This review targets predicted the change in temperature and humidity in previous studies. Objectives of the present study establish what is known about moisture and temperature conditions in climate and any measurable shifts in Iraq's mean monthly temperatures over the last few decades are assessed.
\end{abstract}

Keywords: Temperature, Humidity, Climate Change.

\section{Introduction}

Climate variation has now established itself as one of the world's most pressing environmental concerns. [1]. The global energy balance has changed as a result of increased atmospheric greenhouse gas concentrations, in the previous century, there was rapid industrialization and intensive use of fossil fuels. [2, 3, and 4].Changes in Earth's energy balance as a result of changes in atmospheric chemistry have resulted in a shift in global climate. The temperature of the Earth has risen by $0.74^{\circ} \mathrm{C}$ in the last hundred years, according to reports (1906-2005). With a rate of $0.15^{\circ} \mathrm{C}$ per decade after 1970 , the rise became even more important.[5] Temperatures are rising at a regional scale in response to global warming [6, 7, 8, and 9]. Temperature fluctuations, as well as temperature extremes, are influenced by temperature changes $[10 ; 11]$. The consequences of these changes are particularly significant in areas that are already stressed, such as arid areas with frequent temperature variations. Arid areas are sometimes seen regarded as being among the most vulnerable to climate change [12]. According to [5] rising temperatures in Asia's arid regions could result in a few-fold increase in potential evapotranspiration, resulting in extreme water stress, degradation a lack of food availability, and an increase in the number of people at risk of going hungry Iraq has a largely arid climate, which has resulted in regular temperature extremes. During the month of July, a strong ridge of high pressure normally exists over the Middle East, resulting in an intense heat wave [13]. The warming of the sea as a result of global warming could result in high humidity and a rise in WBT in the Middle East. As a result, the country is widely regarded as vulnerable to climate change. Iraq has been identified as one of the Arab region's most vulnerable countries to climate change [14].

In recent years, the world has seen an increase in summer heat waves. The temperature in the southern city of Basrah hit 54 degrees Celsius on July 22, 2016. Public health [15], agriculture [16], the atmosphere [17], electricity demands [18], and the economy [19] are all linked to temperature extremes. As a result, studying high

*Corresponding Author: zahraaazahraa8@gmail.com 
weather patterns in the light of global climate change is important.

Mayowa, O.O. et al., [20] The Mann- Kendall measure, Sen's slope estimator, and linear regression were used to evaluate patterns in surface air temperatures at eleven stations from 1972 to 2011. At most Iraqi stations, the average minimum and maximum temperatures in Iraq have been trending upward at most stations.

Muslih, K.D. and Błażejczyk, K. [21] Using linear regression and the Mann-Kendall (MK) test, So far, no research has been done in Iraq to determine increases in temperature-related extremes. Furthermore, the patterns in DTR, which is regarded as a climate change fingerprint [22] So far, no research has been done in Iraq. Studies in neighboring countries, on the other hand, show that temperature-related extremes are increasing in the area $[23,24 ; 25]$. Table 1 summarizes the findings of those surveys. This highlights the importance of assessing temperature extremes in Iraq.

The non-parametric Mann-Kendall (MK) test is the most often used for hydrological pattern analysis because it is resistant to outliers, has no distribution, and has a low sensitivity to sudden breaks in time series[26, 27].However, optimistic serial autocorrelation in the data has been discovered to increase the likelihood of pattern relevance in the MK test. [28, 29] The data was pre-whitened, with serial correlation eliminated first and the pattern test conducted on the uncorrelated residuals. The existence of longterm persistent, the MK test's meaning is influenced by time series. [30].

Tabari, H. and Talaee, P.H., [31] and UNDP [32] The MK approach was changed. As a result, the updated Mann-Kendall (MK) test is used in this analysis to validate the validity of the MK test for previously observed Excesses of temperature in the Middle East
Table 1. An analysis of the literature on weather forecasts in the Middle East using Global Climate Models (GCM).

\begin{tabular}{|c|c|c|}
\hline References & Region & Major Findings \\
\hline [33] & $\begin{array}{l}\text { The Eastern } \\
\text { Mediterranean } \\
\text { region }\end{array}$ & $\begin{array}{l}\text { A warming of 1.1- } \\
2.6{ }^{\circ} \mathrm{C} \text { for different } \\
\text { RCPs. }\end{array}$ \\
\hline [34] & $\begin{array}{l}\text { The Middle East } \\
\text { and North Africa }\end{array}$ & $\begin{array}{l}\text { The maximum } \\
\text { temperature would } \\
\text { have risen to almost } \\
50^{\circ} \mathrm{C} \text {. }\end{array}$ \\
\hline [35] & $\begin{array}{l}\text { Persian Gulf } \\
\text { region }\end{array}$ & $\begin{array}{l}\text { Temperatures can } \\
\text { rise above a point } \\
\text { where humans are } \\
\text { unable to adapt. }\end{array}$ \\
\hline [36] & $\begin{array}{l}\text { Persian Gulf } \\
\text { region }\end{array}$ & $\begin{array}{l}\text { Regional climate } \\
\text { model models have } \\
\text { a significant warm } \\
\text { bias. }\end{array}$ \\
\hline [37] & Iran & $\begin{array}{l}\text { In the years } 2007- \\
2010 \text {, the average } \\
\text { temperature will } \\
\text { rise by around } \\
0.5^{\circ} \mathrm{C} \text { to } 5^{\circ} \mathrm{C} \text {. }\end{array}$ \\
\hline [38] & $\begin{array}{l}\text { Southwest of } \\
\text { Iran }\end{array}$ & $\begin{array}{l}\text { Temperature rise } \\
\text { of } 1.69-6.88 \\
\text { degrees Celsius by } \\
\text { the end of the } \\
\text { century. }\end{array}$ \\
\hline [39] & $\begin{array}{l}\text { Southwest of } \\
\text { Iran }\end{array}$ & $\begin{array}{l}\text { Temperature rises } \\
\text { between } 1.12 \text { and } \\
7.87^{\circ} \mathrm{C} \text { by the end } \\
\text { of the century. }\end{array}$ \\
\hline [40] & $\begin{array}{l}\text { Euphrates-Tigris } \\
\text { Basin(Turkey, } \\
\text { Iran, Iraq, Syria) }\end{array}$ & $\begin{array}{l}\text { The annual } \\
\text { temperature } \\
\text { increased by } 6.1^{\circ} \mathrm{C} \\
\text { at the highest point } \\
\text { in the last century. }\end{array}$ \\
\hline [22] & Kuwait & $\begin{array}{l}\text { In recent years, the } \\
\text { daily mean } \\
\text { temperature has } \\
\text { risen during heat } \\
\text { waves, according to } \\
\text { the 1961-1990 } \\
\text { average. }\end{array}$ \\
\hline
\end{tabular}


Lelieveld, J. et al., [41] .Tested the susceptibility of the downscaling process to rainfall and soil degradation using both tacit and obvious approaches for expanding monthly rainfall and temperature. The implicit approach adjusts local scale time series using aggregated variations in the weather component on the GCM scale. The implicit approach can be used in national scale studies, but the clear methodology should be used for local scale studies, according to the findings of that study.

Pal, J.S. and Eltahir, E.A [42] on the native grid scale, water vapor pressure, dewpoint temperature, dewpoint deficiency, and relative humidity $(\mathrm{RH})$ are the four GCM factors used to calculate surface humidity.

Marcella, M.P. and Eltahir [43] It was discovered that using the GCM grid scale vector as the only predictor to get the matching predict and at a local scale yields better results than using several GCM predictors.

\section{Humidity}

The level of moisture in the air is referred to as humidity. As a result, it's a significant part of the hydrological cycle that influences nature and climate [44]. The 2014 winter floods in southern England were attributed to climate change caused by greenhouse gases, with two-thirds of the risk being due to increased water carrying capacity of the atmosphere[45] .

Humidity is used in a variety of areas, including hydrology, geography, irrigation, and medicine, but only in the sense of RH [46]. One of the most essential factors to consider when estimating evapotran spiration is $\mathrm{RH}$ [47]. The evaporation rate rises as the air becomes moister [48]. Photosynthetic rates, tissue temperatures, plant water potentials, and nutrient concentrations are all influenced by humidity.by controlling the time of leaf wetness[49]
$\mathrm{RH}$ is considered to have overt effects on neurological mechanisms (such as eye inflammation and asthma) as well as indirect effects on pathogenic species and chemicals in the medical industry.[50]

Schaller N, et al., [52] Long-term exposure to temperatures with a wet-bulb temperature of more than $35^{\circ} \mathrm{C}$ may be intolerable, according to the report. They also showed that in a shifting climate, a $4^{\circ} \mathrm{C}$ rise in wet-bulb temperature could expose more than half of the world's population to unparalleled environmental factors on a yearly basis. Sun fatigue, heat stroke, and heat tension likely mortality are all potential consequences based on an individual's health status.[53]

According to Penman HL. [54], Buildings account for one-third of global greenhouse gas emissions and absorb more than $40 \%$ of total global energy supply. The potential for a shift in energy use in an energy demand zone exposed to outdoor climate change, especially temperature and humidity, is one of the major issues. [55 and $56]$.

\section{Temperature}

Since it has such a strong impact on our lives, temperature is one of the greatest powerful aspects of Meteorological and Climatological Apparatuses. In the twentieth century, the global average surface temperature rose by around $0.5^{\circ} \mathrm{C}(0.60 \mathrm{C})$. Recent surveys have shown a substantial global warming and a general rise in the frequency and persistence of high temperatures; one of the main issues of this future climate change is the increase in weather events. The greenhouse effect, as a result of rising emissions of carbon dioxide and other greenhouse gases into the atmosphere, has caused global surface temperatures to rise over the past 100 years. There have been significant temporal and spatial variations in this warming pattern [57]. In the twentieth century, global 
mean air surface temperature increased, and in the twenty-first century, it is predicted to increase by (1.8-4.06oC) [58]. Since the global and regional impacts of global warming have become evident, the number of reports on global and regional climate change has risen dramatically in recent decades.

According to (IPCC), the global regular surface air temperature has bigger by $(0.1360 \mathrm{C})$ to $(0.036 \mathrm{oC})$ every decade during the last 50 years. (IPCC) is one of the most significant organizations that provides statistics on global warming trends, and it was established in 1988 [59]. Many regional surveys have also shown a favorable rise in temperature, but the increases differ significantly from one region to the other. The average mean temperature in the south parts of Canada has risen between $(0.560 \mathrm{C})$ and $(1.5860 \mathrm{o})$ over the twentieth century. Over the last 30 years, Europe has seen the greatest growth $(0.436 \circ \mathrm{o})$ [60]. Temperatures are rising globally, not only in the mean annual temperature, but also in the seasonal, monthly, high, and minimum temperatures [61]. Temperatures have risen in both hemispheres, according to a global survey of air temperature fluctuations and surveys. However, in the last 50 years, warming has been more prominent in the northern hemisphere [62]. Many regional surveys have also found a warming pattern, but the shifts differ significantly from one country to the next [63]. The Mediterranean is the world's most impacted region by global warming, and these elevated temperatures may lead to evaporation, water scarcity, and forest fire risk.[64]

\section{Effect of Greenhouse Gases}

Increased atmospheric greenhouse gas concentrations in the last century as a result of rapid industrialization and extensive use of fossil fuels have altered the global energy balance [65] and, as a result, increased the earth temperature by $0.15^{\circ} \mathrm{C}$ per decade in the last half of the last century [5]. Climate change as a result of the temperatures has impacted nearly every ecological and human sector on the planet. As a result, climate change is regarded as one of the most serious environmental issues that the global world has ever faced [1]. Temperatures on a regional scale are that in tandem with global warming [66]. However, temperature changes in some areas are much greater than the global average. Temperature fluctuations result in changes in temperature variability, changes in averages, and, as a result, extreme temperature events [67]. The consequences of these changes are especially important for areas that are already stressed, such as arid regions where temperature fluctuations are frequent [68]. As a result, the possibility of climate change is far greater in MENA's arid and semiarid regions.

According to Braganza, K. et al., [5] a rise in temperature in an arid area of Asia may result in a few-fold increase in possible evapotranspiration, resulting in extreme water stress, degradation of food security, and an increase in the number of people at risk of hunger.

Iraq, which is situated in the Middle East and North Africa (MENA), has a mainly arid climate with regular temperature extremes. Iraq has been identified as one of the most vulnerable countries in the Arab region to climate change. [67], the temperature in Iraq is rising 2 to 7 times higher than the global average, according to the report. It is expected that global warming will allow the temperature in Iraq to continue to rise. Table 1 provides a summary of some of the findings. According to the reports, the region's temperature is expected to rise sharply in the future, potentially raising weather waves past the threshold for human adaptation and putting the population at risk [35]. As a result, accurate 
temperature projections in Iraq are critical for necessary adaptation and mitigation preparation.

\section{Environment Risks and Climate Change In Iraq}

Iraq's biodiversity has been under threat from a variety of factors, including population increase, three wars' consequences, climate change, insufficient land use design, and advance on sensitive ecosystems.[70]

- Iraq's average mean temperature rose by 1-2 degrees Celsius between 1970 and 2004 [70]. Iraq has no precipitation, and the rest of the country is arid or semi-arid. Annual rainfall has varied from 1951 to 2000, with both raises (northeast Iraq) and declines (southeast Iraq) (southeast and west Iraq).

- Higher temperatures, extreme heat waves, a reduction in mean annual rainfall but an increase in severity, a decline in runoff, and sea level rise in the Gulf are all predicted for Iraq in the future [71]. The agriculture sector, water supplies, human health, the oil sector, and infrastructure in Iraq are all predicted to suffer as a result of these reforms.[72]

Matiu, M., et al., [73] Discovered substantial drought exacerbation across Iraq from 1998 to 2009, as well as two significant drought cycles from 1998 to 1999 and 2007 to 2008. Droughts have been more severe in Iraq's central and southwestern regions, with more prolonged yet shorter droughts. Long-term drought has wreaked havoc on Iraq's rain-fed crops in the north.

\section{Description of Iraq Climate}

Iraq is $438,320 \mathrm{~km} 2$ in size and is placed in southwest Asia (Lat: $29^{\circ} 15^{\circ} \mathrm{N}-38^{\circ} 15^{\circ} \mathrm{N}$ and Long: $\left.\quad 38^{\circ} 45-48^{\circ} 45^{\circ} \mathrm{E}\right)$. Iraq's topography resembles a vast basin, with the Mesopotamian alluvial plains of the Tigris and Euphrates flanked on three sides by mountains rising to 3,550 meters [74]. Iraq's temperature varies greatly from place to place. Based on topography and geography, the country can be divided into four regions (Fig. 1) [75]: Zone-I: the northern and northeastern mountainous area, which has a Mediterranean climate and covers $21 \%$ of the country; Zone II refers to the swelling land in the south and west of the mountainous area, which covers $9.6 \%$ of the country and has a steppe atmosphere. Zone-III: which covers 30.2 percent of the country and has a subtropical semiarid climate, is located in the country's central and southern regions. Zone-IV: which is an expansion of the Syrian and Arabian deserts and protections 39.2 percent of the land, has a continental desert atmosphere and covers 39.2 percent of the land.

Iraq's climate is divided into two terms: a hot and dry summer from June to September, and a cool and gloomy winter from November to March. Around November and April, about $90 \%$ of the annual rainfall falls, with the remainder of the year becoming exceptionally dry [76]. The central and southern deserts get less than 100 millimeters of rain a year, while northern Iraq's mountainous province receives more than 1,000 millimeters.

In the summer, the average lowest temperature is around $27-31{ }^{\circ} \mathrm{C}$, with maximum temperatures between 41 and $45^{\circ} \mathrm{C}$ [75]. Due to a lack of rain and excessive drought, a substantial portion of Iraq has become a desert. The country's harsh climatic conditions and varied topography have made it especially vulnerable to natural disasters, particularly hydrological disasters such as drought $[77,78]$. 


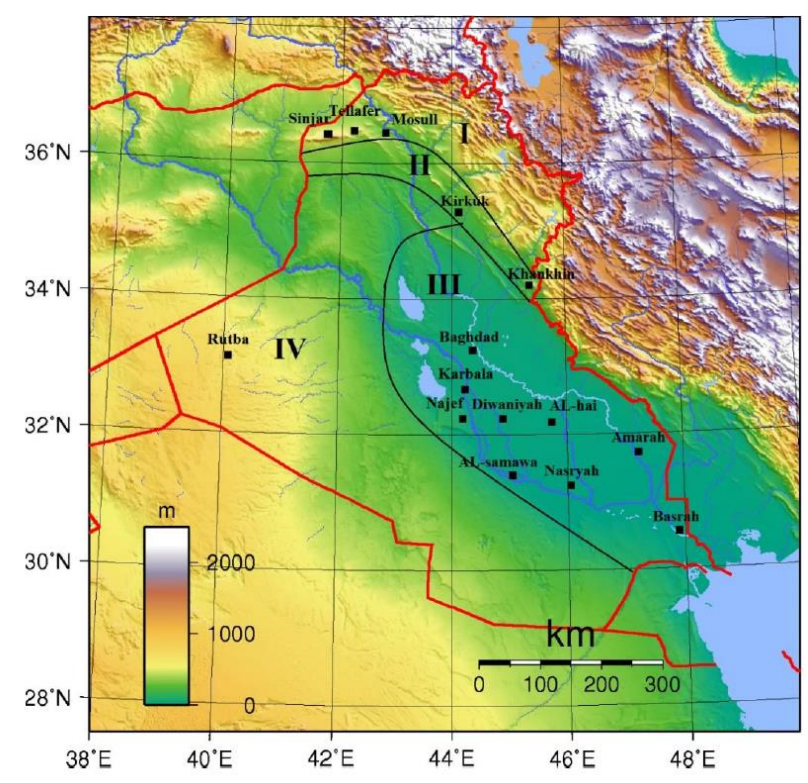

Figure 1. Iraq's climatic zones and temperature gauge locations.

\section{Conclusions}

This review paper has briefly introduced the literature review in the Middle Eastern region and climate change of Iraq in the past years.

\section{Acknowledgements}

The authors acknowledge the faculty and staff of the environment engineering, Mustansiriyah University, for their valuable help in this research.

\section{Conflict of Interest}

This research did not receive any specific grant from funding agencies in the public, commercial, or not for profit sectors.

\section{References}

1. Abatan, A.A., Abiodun, B.J., Lawal, K.A., Gutowski, W.J., (2015). Trends in extreme temperature over Nigeria from percentilebased threshold indices. International Journal of Climatology. 36(6), 2527-2540. doi: 10.1002/joc.4510.

2. Al Senafi, F., Anis, A., (2015). "Shamals and climate variability in the Northern Arabian/Persian Gulf from 1973 to 2012”.
International Journal of Climatology 35(15), 4509-4528. doi: 10.1002/joc.4302.

3. Barros, V.R., Boninsegna, J.A., Camilloni, I.A., Chidiak, M., Magrín, G.O., Rusticucci, M., (2015). "Climate change in Argentina: trends, projections, impacts and adaptation". Wiley Interdisciplinary Reviews: Climate Change, 6(2), 151-169. doi:10.1002/wcc.316.

4. Braganza, K., Karoly, D., Hirst, A., Mann, M., Stott, P., Stouffer, R., Tett, S., (2003). "Simple indices of global climate variability and change: Part I-variability and correlation structure". Climate Dynamics, 20(5), 491502. Doi: 10.1007/s00382-002-0286-0.

5. Cardil, A., Salis, M., Spano, D., Delogu, G., Molina, T. D., (2014). "Large wildland fires and extreme temperatures in Sardinia (Italy)". Iforest- Biogeosciences and Forestry 7(3), 162. doi: 10.3832/ifor1090-007.

6. Chu, J.T., Xia, J., Xu, C.Y., Singh, V.P., (2010). "Statistical downscaling of daily mean temperature, pan evaporation and precipitation for climate change scenarios in Haihe River, China”. Theoretical and Applied Climatology 99(1-2), 149-161. Doi: 10.1007/s00704-009-0129-6.

7. Dutta, S., Chaudhuri, G., (2015). "Evaluating Environmental Sensitivity of Arid and Semiarid Regions in Northeastern Rajasthan, India”. Geographical Review, 105(4), 441461. doi: 10.1111/j.1931-0846.2015.12093.x.

8. Fathian, F., Aliyari, H., Kahya, E., Dehghan, Z., (2016). "Temporal trends in precipitation using spatial techniques in GIS over Urmia Lake Basin, Iran". International Journal of Hydrology Science and Technology, 6(1), 6281. doi: 10.1504/IJHST.2016.073883.

9. Ghasemi, A.R., (2015). "Changes and trends in maximum, minimum and mean temperature series in Iran". Atmospheric Science Letters 16(3), 366-372. doi: 10.1002/as12.569. 
10. Hamed, K.H., (2007). “Trend detection in hydrologic data: the Mann-Kendall trend test under the scaling hypothesis". Journal of hydrology, 349(3), 350-363. doi.org/10.1016/j.jhydrol.2007.11.009.

11. Hamed, K.H., (2009). "Exact distribution of the Mann-Kendall trend test statistic for persistent data".Journal of Hydrology, 365(1), 86-94. doi: 10.1016/j.jhydrol.2008.11.024.

12. Hamed, K.H., Rao, A.R., (1998) “A modified Mann-Kendall trend test for auto correlated data". Journal of Hydrology, 204(1-4), 182-196. doi: 10.1016/S00221694(97)00125-X.

13. Hereher, M.E., (2016). "Recent trends of temperature and precipitation proxies in Saudi Arabia: implications for climate change".2016. Arabian Journal of Geosciences $9(11), \quad 575 . \quad$ Doi: 10.1007/s12517-016-2605-5.

14. Huang, C., Barnett, A.G., Wang, X., Vaneckova, P., FitzGerald, G., Tong, S., (2011). "Projecting future heat-related mortality under climate change scenarios: a systematic review". Environmental health perspectives, $\quad 119(12), 1681$. doi.org/10.1289/ehp.1103456.

15. IPCC (2013). "Climate change 2013: the physical science basis. In Contribution of Working Group I to the Fifth Assessment Report of the Intergovernmental Panel on Climate Change", Stocker, T.F, Qin, D., Plattner, G-K., Tignor, M., Allen, S.K., Boschung, J., Nauels, A., Xia, Y., Bex, V., Midgley, P.M., (eds). Cambridge University Press: Cambridge, UK and New York, NY; $1535 \mathrm{pp}$.

16. Karagiannis, T., Molle, M., Faloutsos, M., (2004) 'Long-range dependence ten years of Internet traffic modeling".2004. IEEE internet computing, 8(5), 57-64. doi:10.1109/MIC.2004.46.
17. Koutsoyiannis, D., (2003) "Climate change, the Hurst phenomenon, and hydrological statistics". Hydrological Sciences Journal, 48(1), 3-24. doi: 10.1623/ hysj.48.1.3.43481

18. Liu, X., Sweeney, J., (2012) “Modelling the impact of urban form on household energy demand and related $\mathrm{CO} 2$ emissions in the Greater Dublin Region”. Energy Policy 46, 359369. doi.org/10.1016/j.enpol.2012.03.070.

19. Matiu, M., Ankerst, D.P., Menzel, A., (2016) "Asymmetric trends in seasonal temperature variability in instrumental records from ten stations in Switzerland, Germany and the UK from 1864 to 2012”. International Journal of Climatology 36(1), 13-27. doi: 10.1002/joc.4326.

20. Mayowa, O.O., Pour, S.H., Shahid, S., Mohsenipour, M., Harun, S.B., Heryansyah, A., Ismail, T., (2015) "Trends in rainfall and rainfall-related extremes in the east coast of peninsular Malaysia". Journal of Earth System Science, 124(8), 1609-1622. doi:10.1007/s12040-015-0639-9

21. Muslih, K.D., Błażejczyk, K., (2016) "The inter-annual variations and the long-term trends of monthly air temperatures in Iraq over the period 1941-2013”. Theoretical and Applied Climatology, 1-14. doi:10.1007/s00704-016-1915-6

22. Nasrallah, H.A., Nieplova, E., Ramadan, E., (2014) "Warm season extreme temperature events in Kuwait”. Journal of Arid Environments, 56(2), 357-371. doi:10.1016/S0140- 1963(03)00007-7.

23. Niero, M., Ingvordsen, C.H., PeltonenSainio, P., Jalli, M., Lyngkjær, M.F., Hauschild, M.Z., Jørgensen, R.B., (2015) "Eco-efficient production of spring barley in a changed climate: A Life Cycle Assessment 
including primary data from future climate scenarios". Agricultural Systems, 136, 46-60. doi.org/10.1016/j.agsy.2015.02.007

24. Prasad, P.V.V., Pisipati, S.R., Ristic, Z., Bukovnik, U., Fritz, A.K., (2008). "Impact of nighttime temperature on physiology and growth of spring wheat". Crop Science, 48(6), 2372-2380.

doi:10.2135/cropsci2007.12.0717.

25. Robaa, E.S.M., Al-Barazanji, Z., (2015) "Mann-Kendall trend analysis of surface air temperatures and rainfall in Iraq". IDOJARAS, 119(4), 493-514.

26. Salguero-Gómez, R., Siewert, W., Casper, B.B., Tielbörger, K., (2012). " $A$ demographic approach to study effects of climate change in desert plants. Philosophical Transactions of the Royal Society of London B”. Biological Sciences 367(1606), 31003114. doi: 10.1098/rstb.2012.0074.

27. Sarli, J., Lutermann, H., Alagaili, A.N., Mohammed, O.B., Bennett, N.C., (2016). "Seasonal reproduction in the Arabian spiny mouse, Acomys dimidiatus (Rodentia: Muridae) from Saudi Arabia: The role of rainfall and temperature". Journal of Arid Environments 124, 352-359. doi.org/10.1016/j.jaridenv.2015.09.008.

28. Shahid, S., (2010). "Recent trends in the climate of Bangladesh. Climate Research". 42(3), 185- 193. doi: 10.3354/cr00889.

29. Shahid, S., (2012). "Vulnerability of the power sector of Bangladesh to climate change and extreme weather events". Regional Environmental Change 12(3), 595-606. Doi: 10.1007/s10113-011-0276-z.

30. Song, C., Pei, T., Zhou, C., (2014). “The role of changing multiscale temperature variability in extreme temperature events on the eastern and central Tibetan Plateau during 1960-2008”. International Journal of
Climatology 34(14), 3683-3701. doi: 10.1002/joc.3935.

31. Tabari, H., Talaee, P.H., (2011) "Analysis of trends in temperature data in arid and semi-arid regions of Iran”. Global and Planetary Change 79(1), 1-10. doi.org/10.1016/j.gloplacha.2011.07.008.

32. UNDP. Elasha BO., (2010) “Mapping of climate change threats and human development impacts in the Arab region". UNDP Arab Development ReportResearch Paper Series,. Springer Science \& Business Media. doi: 10.1007/978-94-007-4988-7.

33. Wang, X.J., Zhang, J.Y., Shahid, S., Guan, E.H., Wu, Y.X., Gao, J., He, R.M., (2016) "Adaptation to climate change impacts on water demand. Mitigation and Adaptation Strategies for Global Change”. 21(1), 81-99. doi: 10.1007/s11027-014- 9571-6

34. Wentz, F.J., Ricciardulli, L., Hilburn, K., Mears, C., (2007) "How much more rain will global warming bring”. Science, 317(5835), 233-235. doi: 10.1126/science. 1140746

35. Xiang, J., Bi, P., Pisaniello, D., Hansen, A., Sullivan, T., (2014). "Association between high temperature and work-related injuries in Adelaide, South Australia, 2001- 2010”. Occup Environ Med, 71(4), 246-252. doi:10.1136/oemed-2013-101584

36. Yue, S., Pilon, P., Cavadias, G., (2002). "Power of the Mann-Kendall and Spearman's rho tests for detecting monotonic trends in hydrological series". Journal of hydrology, 259(1), 254-271. doi:10.1016/S0022 1694(01)00594-7

37. Yue, S., Wang, C., (2004). "The MannKendall test modified by effective sample size to detect trend in serially correlated hydrological series". Water Resources Management, 18(3), 201-218. doi: 10.1023/B:WARM.0000043140.61082.60. 
38. Zamani, R., Mirabbasi, R., Abdollahi, S., Jhajharia, D., (2016). "Streamflow trend analysis by considering autocorrelation structure, long-term persistence, and Hurst coefficient in a semi-arid region of Iran". Theoretical and Applied Climatology, 129(12), 33- 45. doi: 10.1007/s00704-016-1747-4

39. Zhang, X., Aguilar, E., Sensoy, S., Melkonyan, H., Tagiyeva, U., Ahmed, N., Albert, P., (2005). "Trends in Middle East climate extreme indices from 1950 to 2003”. Journal of Geophysical Research: Atmospheres, 110(D22). doi: 10.1029/2005JD006181.

40. Peleg, N., Bartov, M. and Morin, E., (2015). "CMIP5-predicted climate shifts over the East Mediterranean: implications for the transition region between Mediterranean and semi-arid climates". International Journal of Climatology, 35(8), pp.2144-2153. https://doi.org/10.1002/joc.4114

41. Lelieveld, J., Proestos, Y., Hadjinicolaou, P., Tanarhte, M., Tyrlis, E. and Zittis, G., (2016). "Strongly increasing heat extremes in the Middle East and North Africa (MENA) in the 21st century". Climatic Change, 137(1-2), pp.245-260. https://doi.org/10.1007/s10584016-1665-6

42. Pal, J.S. and Eltahir, E.A., (2016) "Future temperature in southwest Asia projected to exceed a threshold for human adaptability”. Nature Climate Change, 6(2), p.197. https://doi.org/10.1038/nclimate2833

43. Marcella, M.P. and Eltahir, E.A., (2012). "Modeling the summertime climate of Southwest Asia: The role of land surface processes in shaping the climate of semiarid regions". Journal of Climate, 25(2), pp.704719. https://doi.org/10.1175/2011JCLI4080.1 44. Najafi, R. and Kermani, M.R.H., (2017). "Uncertainty Modeling of Statistical Downscaling to Assess Climate Change
Impacts on Temperature and Precipitation”. Water resources management, 31(6), pp.1843-1858.

https://doi.org/10.1007/s11269-017-1615-8

45. Önol, B. and HM Semazzi, F., (2009). "Regionalization of climate change simulations over the Eastern Mediterranean". Journal of Climate, 22(8), pp.1944-1961. https://doi.org/10.1175/2008JCLI1807.1

46. Zarenistanak, M., Dhorde, A.G. and Kripalani, R.H., (2014). "Temperature analysis over southwest Iran: trends and projections". Theoretical and applied climatology, 116(1-2), pp.103-117. https://doi.org/10.1007/s00704-013-0913-1

47. Zarenistanak, M., Dhorde, A.G., Kripalani, R.H. and Dhorde, A.A., (2015). "Trends and projections of temperature, precipitation, and snow cover during snow cover observed period over southwestern Iran". Theoretical and Applied Climatology, 122(3-4), pp.421-440. https://doi.org/10.1007/s00704-014-1287-8

48. Bozkurt, D. and Sen, O.L., (2013). "Climate change impacts in the EuphratesTigris Basin based on different model and scenario simulations". Journal of hydrology, 480, pp.149-161.

https://doi.org/10.1016/j.jhydrol.2012.12.02

49. ZhangXC. (2007). "Acomparison of explicit and implicit spatial downscaling of GCM output for soil erosion and crop production assessments". Clim. Change 84: 337-363.

50. Huth R. (2005). "Downscaling of humidity variables: a search for suitable predictors and predictands". Int. J. Climatol. 25: 243-250.

51. Widmann M, Bretherton CS, Salathe EP Jr. (2003). "Statistical precipitation downscaling over the northwestern United States using numerically simulated 
precipitation as a predictor". J. Clim. 16: 799-816.

52. Schaller N, Kay AL, Lamb R, Massey NR, van Oldenborgh GJ, Otto FEL. (2016). "Human influence on climate in the 2014 southern England winter floods and their impacts". Nat. Clim. Change 6: 627-634. https://doi.org/10.1038/nclimate2927.

53. Trenberth KE, Dai A, Rasmussen RM, Parsons DB. (2003). "The changing character of precipitation". Bull. Am. Meteorol. Soc. 84: 1205-1217.

54. Penman HL. (1948). "Natural evaporation from open water, bare soil and grass". Proc. R. Soc. A 193: 120-145.

55. Allen RG, Pereira LS, Raes D, Smith M. (1998). "Crop Evapotranspiration -Guidelines for Computing Crop Water Requirements". FAO Irrigation and drainage paper 56. Food and Agriculture Organization of the United Nations: Rome. ISBN 92-5104219-5.

56. Webster IT, Sherman BS. (1995). "Evaporation from fetch-limited water bodies". Irrig. Sci. 16: 53-64.

57. Sentelhas PC, Dalla MA, Orlandini S, Santos EA, Gillespie TJ, Gleason ML. (2008). "Suitability of relative humidity as an estimator of leaf wetness duration”. 2008. Agric. For. Meteorol. 148: 392-400.

58. Tibbitts TW. (1979). "Humidity and plants". Bioscience 29: 358-363.

59. Sherwood SC, Huber M. (2010). “An adaptability limit to climate change due to heat stress". Proc. Natl. Acad. Sci. U.S.A. 107: 9552-9555.

60. Hill SF. (2002). "Management of heat related illness enhanced by climate change and global warming in the North West Kimberley region of Western Australia”. 2002. J. Rural Remote Environ. Health 1: 1318.
61. Yau YH, Hasbi S. (2013). "A review of climate change impacts on commercial buildings and their technical services in the tropics". Renewable Sustainable Energy Rev. 18: 430-441.

62. Wang X, Chen D, Ren Z. (2010). "Assessment of climate change impact on residential building heating and cooling energy requirement in Australia”. Build. Environ. 45: 1663-1682.

63. Ren Z, Chen Z, Wang X. (2013). "Climate change adaptation pathways for Australian residential buildings". Build. Environ. 46: 2398-2412.

64. Huang, W.R., Wang, S.Y. and Chan, J.C., (2011). "Discrepancies between global reanalyses and observations in the interdecadal variations of Southeast Asian cold surge". International Journal of Climatology, 31(15), pp.2272-2280. https://doi.org/10.1002/joc. 2234

65. IPCC, Thomas Stocker, Dawei Qin, Dawei Qin, M. Tignor, S.K. Allen, J. Boschung, Alexander Nauels, Y. Xia, V. Bex, P.M. Midgley . (2013). "The physical science basis. In Contribution of Working Group I to the Fifth Assessment Report of the Intergovernmental Panel on Climate Change". Cambridge University Press: Cambridge, UK and New York, NY; 1535 pp. 66. G.-K., Tignor, M., Allen, S.K., Boschung, J., Nauels, A., Xia, Y., Bex, V., Midgley, P.M. (Eds.), (2013). "Contribution of Working Group I to the Fifth Assessment Report of the Intergovernmental Panel on Climate Change”. Cambridge University Press, Cambridge, UK and New York, NY (1535 pp).

67. Wang, X.J., Zhang, J.Y., Shahid, S., Guan, E.H., Wu, Y.X., Gao, J. and He, R.M., (2016). "Adaptation to climate change impacts on water demand. Mitigation and 
Adaptation Strategies for Global Change”. 21(1), pp.81-99.

https://doi.org/10.1007/s11027-014- 9571-6.

68. Keggenhoff, I., Elizbarashvili, M., Amiri-Farahani, A. and King, L., (2014). "Trends in daily temperature and precipitation extremes over Georgia, 19712010". Weather and climate extremes, 4, pp.75-85.

https://doi.org/10.1016/j.wace.2014.05.001.

69. Mayowa, O.O., Pour, S.H., Shahid, S., Mohsenipour, M., Harun, S.B., Heryansyah, A. and Ismail, T., (2015). "Trends in rainfall and rainfall-related extremes in the east coast of peninsular Malaysia”. Journal of Earth System Science, 124(8), pp.1609-1622. https://doi.org/10.1007/s12040-015-0639-9

70. Ghasemi, A.R., (2015). "Changes and trends in maximum, minimum and mean temperature series in Iran". Atmospheric Science Letters, 16(3), pp.366-372. https://doi.org/10.1002/asl2.569

71. Abatan, A.A., Abiodun, B.J., Lawal, K.A. and Gutowski, W.J., (2016). "Trends in extreme temperature over Nigeria from percentile-based threshold indices". International Journal of Climatology, 36(6), pp. 2527-2540.

https://doi.org/10.1002/joc.4510.

72. Salman, S.A., Shahid, S., Ismail, T., Chung, E.S. and Al-Abadi, A.M., (2017a). "Long-term trends in daily temperature extremes in Iraq". Atmospheric Research, 198 , pp.97107.https://doi.org/10.1016/j.atmosres.2017.0 $\underline{8.011}$

73. Matiu, M., Ankerst, D.P. and Menzel, A., (2016). "Asymmetric trends in seasonal temperature variability in instrumental records from ten stations in Switzerland, 79.
Germany and the UK from 1864 to 2012". International Journal of Climatology, 36(1), pp.13-27. https://doi.org/10.1002/joc.4326

74. Salguero-Gómez, R., Siewert, W., Casper, B.B. and Tielbörger, K., (2012). “ $A$ demographic approach to study effects of climate change in desert plants". Philosophical Transactions of the Royal Society of London B: Biological Sciences, 367(1606), pp.3100-3114. doi:10.1098/rstb.2012.0074

75. Dutta, S. and Chaudhuri, G., (2015). "Evaluating environmental sensitivity of arid and semiarid regions in Northeastern Rajasthan, India”. Geographical Review, 105(4), pp.441-461. https://doi.org/10.1111/j.19310846.2015.12093.x

76. Ahmed, K., Shahid, S., Chung, E.S., Ismail, T. and Wang, X.J., (2017). "Spatial distribution of secular trends in annual and seasonal precipitation over Pakistan”. Climate Research, 74(2), pp.95-107. https://doi.org/10.3354/cr01489

77. UNDP, Elasha, B.O., (2010). “Mapping of climate change threats and human development impacts in the Arab region". In: UNDP Arab Development Report- Research Paper Series. UNDP Regiona Bureau for the Arab States.

78. World Bank. (2017) "Iraq - Systematic Country Diagnostic (English). Washington, D.C.: World Bank Group”. http://documents.worldbank.org/curated/en/5428 11487277729890/Iraq-Systematic-CountryDiagnostic. 